\title{
Lipopolysaccharide-induced non-specific resistance to systemic Escherichia coli infection in mice
}

\author{
J. VUOPIO-VARKILA, MARJATTA NURMINEN, LIISA PYHÄLÄ and P. H. MÄKELÄ
}

National Public Health Institute, Mannerheimintie 166, SF-00280 Helsinki, Finland

Summary. A high degree of non-specific resistance to a lethal systemic Escherichia coli
infection was induced in mice by pretreatment with a small dose $(<5 \mu \mathrm{g} /$ mouse) of
the homologous lipopolysaccharide (LPS) or with heterologous rough-type LPS from
$E$. coli K-12. The route of LPS administration, intraperitoneally or subcutaneously,
did not influence the development of resistance, suggesting that a systemic cell
activation was responsible for the effect. The enhanced elimination of bacteria was
similar to that in mice recovering from a sublethal $E$. coli infection. In the LPS-
treated mice, elimination of the challenge bacteria from the peritoneal cavity and the
blood started $3-4 \mathrm{~h}$ after challenge whereas, in controls, the bacterial numbers
continued to increase until the mice died. The detoxified LPS derivative,
monophosphoryl lipid A (MPL), also increased the survival of mice infected with $E$.
coli O18:K1. However, the dose of MPL required for optimal infection resistance
was $100-$ fold greater than that of native, E. coli K-12 LPS, corresponding to the $100-$
fold reduced toxicity of MPL for mice and rabbits in lethality and pyrogenicity assays.

\section{Introduction}

Although mice are usually quite resistant to Escherichia coli infection, the mouse virulence of an $E$. coli $\mathrm{O} 18: \mathrm{K} 1 \mathrm{strain}$, isolated from a case of neonatal meningitis, was high (LD50 $4 \times 10^{5}$ bacteria/mouse) (Vuopio-Varkila et al., 1987). An intraperitoneal injection of this strain resulted in peritonitis, followed by increasing numbers of bacteria in the blood. The duration of the infection was short. If the mice survived, the bacterial counts in the mice started to decrease by $24 \mathrm{~h}$, and the animals were free from the infection within $48 \mathrm{~h}$ (Vuopio-Varkila, 1987). Furthermore, if the convalescent mice were challenged after $48 \mathrm{~h}$ with another lethal dose of $E$. coli, they were highly resistant to the infection.

This rapid development of resistance suggested that non-specific resistance mechanisms were important. Many previous studies have shown that immunostimulation with bacterial cell-wall components, such as lipopolysaccharide (LPS), can cause a non-specific increase in infection resistance as well as bactericidal and tumoricidal capabilities (Rowley, 1955; Landy, 1956; Abernathy, 1957; Nowotny, 1985; Chase et al., 1986). LPS is a potent stimulator of many cell types, especially macrophages.

To learn more about the development of resist-

Received 11 Feb. 1987; revised version accepted 1 June 1987. ance, the course of $E$. coli $\mathrm{O} 18: \mathrm{K} 1$ infection in convalescent mice has been compared with that in LPS-pretreated mice. Because of the toxicity of native LPS, we also studied the possibility of eliciting resistance to infection with a LPS derivative, monophosphoryl lipid A, which is reported to be of reduced toxicity (Ribi, 1984; Ribi et al., 1986).

\section{Materials and methods}

\section{Bacterial strains}

For the standard mouse challenge, we used $E$. coli IH 3080 (serotype O18:K1:H7) (Vuopio-Varkila et al., 1987), an isolate from a case of human neonatal meningitis. In some experiments other challenge strains were used: $E$. coli $\mathrm{IH} 23265$ (O18:K5), isolated from neonatal meningitis, and $E$. coli IH $3136(\mathrm{Ol}: \mathrm{K} 1)$, isolated from neonatal septicaemia. All strains were stored at $-70^{\circ} \mathrm{C}$ in skimmed milk in small volumes until used. The inoculum for injection was prepared by growing the bacteria overnight in Luria broth (Miller, 1972) at $37^{\circ} \mathrm{C}$ on a rotatory shaker, then diluting the culture 10 fold in fresh broth and growing for a further $120 \mathrm{~min}$ in the same conditions.

\section{Experimental infection}

$(\mathrm{CBA} \times \mathrm{C} 57 \mathrm{BL} / 6) \mathrm{F} 1$ hybrid mice (8-10 weeks old) bred at this Institute were used in most assays. $\mathrm{C} 3 \mathrm{H} / \mathrm{HeJ}$ mice were obtained from the breeding unit of the Department of Bacteriology and Immunology, University 
of Helsinki and used at 8-16 weeks old. The bacterial challenge (10-fold dilutions of exponentially-growing bacteria in $0.2 \mathrm{ml}$ of saline) was injected intraperitoneally (ip). The LD50 was determined from the day 5 survival data of groups of 6 mice (Reed and Muench, 1938).

\section{Tissue counts of bacteria}

Samples were taken from the bacterial inoculum as well as the peritoneal cavity and blood at different times (three mice for each time point) for measuring the number of viable bacteria ( $\mathrm{cfu}$ ) by plating out a series of dilutions. The blood samples $(100 \mu \mathrm{l})$ were obtained from the retroorbital plexus of mice anaesthetised with ether. Thereafter the mice were killed by cervical dislocation, and the peritoneal fluid was harvested by injecting $2 \mathrm{ml}$ of saline ip and withdrawing $0.5 \mathrm{ml}$ after gentle massaging. The dilution factor was included in all calculations. Each point in the figures represents the number of bacteria (cfu)/total volume of blood or peritoneal fluid and is the geometric mean of results from three mice.

\section{LPS preparations}

E. coli O18 LPS was isolated from strain EH 817 (serotype $018: \mathrm{K}^{-}$), a spontaneous non-capsulate mutant of strain IH 3080 (Vaara et al., 1984), by the phenolwater method (Westphal and Jann, 1965). E. coli K-12 LPS was isolated by the phenol-chloroform-petroleum ether method (Galanos et al., 1969) from strain W3350 received from Dr M. Brammer, University of Leicester. Both LPSs were diluted in water, stored at $-70^{\circ} \mathrm{C}$ in small volumes and sonicated briefly before use. Detoxified endotoxin (monophosphoryl lipid A; MPL) from Salmonella typhimurium $\mathrm{ReG} 30 / \mathrm{C} 21$ was purchased from Ribi Immunochemicals Research Inc., MT., USA and dissolved in triethylamine $0.1 \% \mathrm{v} / \mathrm{v}$ to a concentration of $2 \mathrm{mg} / \mathrm{ml}$.

\section{LPS pretreatment}

LPS preparations $(0 \cdot 1-\mathrm{ml}$ volumes) were injected subcutaneously (sc) or ip into mice at different times before bacterial challenge.

\section{Assays for LPS toxicity}

Pyrogenicity was determined in New Zealand White rabbits by intravenous (iv) injection of the LPS preparations and by monitoring the rectal temperature change according to the European Pharmacopoeia (1971).

Lethality was determined in 12-week-old, F1 CBA $\times$ C57BL/6 mice by ip injection of $12.5 \mathrm{mg}$ of galactosamine diluted in sterile water followed by iv injection of LPS within $1 \mathrm{~h}$. The lethality in mice was recorded after $72 \mathrm{~h}$. (Galanos et al., 1979).

\section{Results}

\section{E. coli $018: K 1$ infection in convalescent mice}

When mice were given a sublethal dose of live $E$. coli $\mathrm{O} 18: \mathrm{K} 1$ by ip injection $\left(0 \cdot 1 \mathrm{LD} 50=4 \times 10^{4} \mathrm{cfu} /\right.$ mouse, which they were able to clear in $24 \mathrm{~h}$ ) and challenged ip $48 \mathrm{~h}$ later with a second bacterial dose, they effectively eliminated an otherwise lethal (10 LD50) E. coli O18:K1 challenge (fig. 1). Thus, by $4 \mathrm{~h}$ after challenge, the bacteria had already grown rapidly in the peritoneal cavities of untreated mice (fig. $2 \mathrm{~A}$ ), whereas in convalescent mice the numbers were already reduced $\left(5.5 \times 10^{5} \mathrm{cfu}\right.$ compared with $7.9 \times 10^{7} \mathrm{cfu}$ in the controls; fig. 1). After $24 \mathrm{~h}$, the inoculum was completely cleared in the convalescent mice and all of the control animals were dead. Correspondingly, the LD50 of the $E$. coli $\mathrm{O} 18: \mathrm{K} 1$ strain was at least 50-fold higher in the convalescent mice than in normal mice $\left(>2 \times 10^{7}\right.$ and $4 \times 10^{5} \mathrm{cfu} /$ mouse, respectively).

\section{E. coli O18: K1 infection in mice pretreated with LPS}

To determine whether comparable resistance to infection could be induced by LPS, $E$. coli O18 LPS was isolated from a non-capsulate mutant of the challenge strain and injected ip $24 \mathrm{~h}$ before chal-

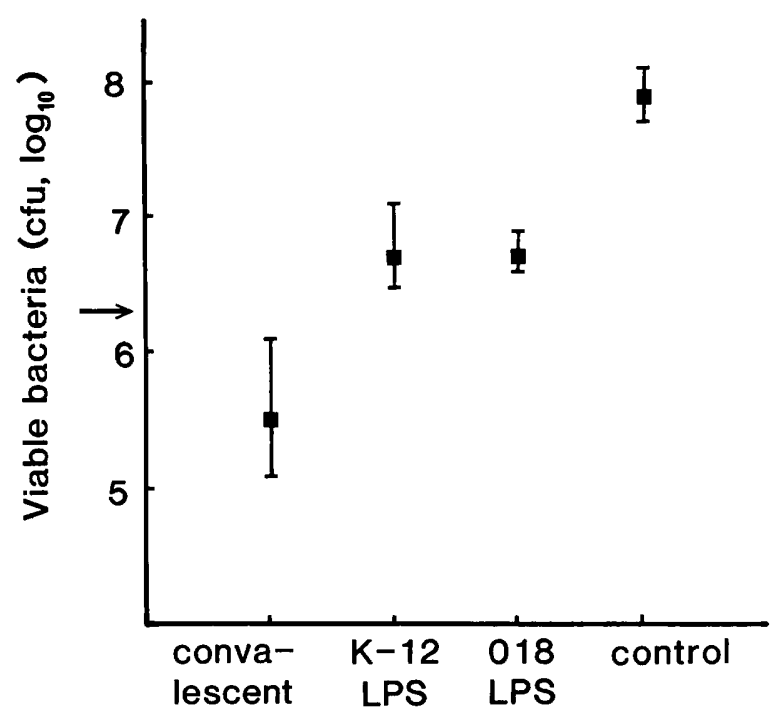

Fig. 1. Viable bacteria in the peritoneal cavity $4 \mathrm{~h}$ after an ip challenge with $4 \times 10^{6} \mathrm{cfu}$ of $E$. coli $\mathrm{O} 18: \mathrm{K} 1$. Mice had been given a sublethal $E$. coli $018: \mathrm{K} 1$ ip infection $48 \mathrm{~h}$ before challenge (convalescent), or $5 \mu \mathrm{g}$ of LPS ip $24 \mathrm{~h}$ before challenge (K-12 LPS or O18 LPS) or no pretreatment (control). The challenge dose is indicated by an arrow. Each point represents the geometric mean of results from three mice; the vertical lines show the scatter between the values. 


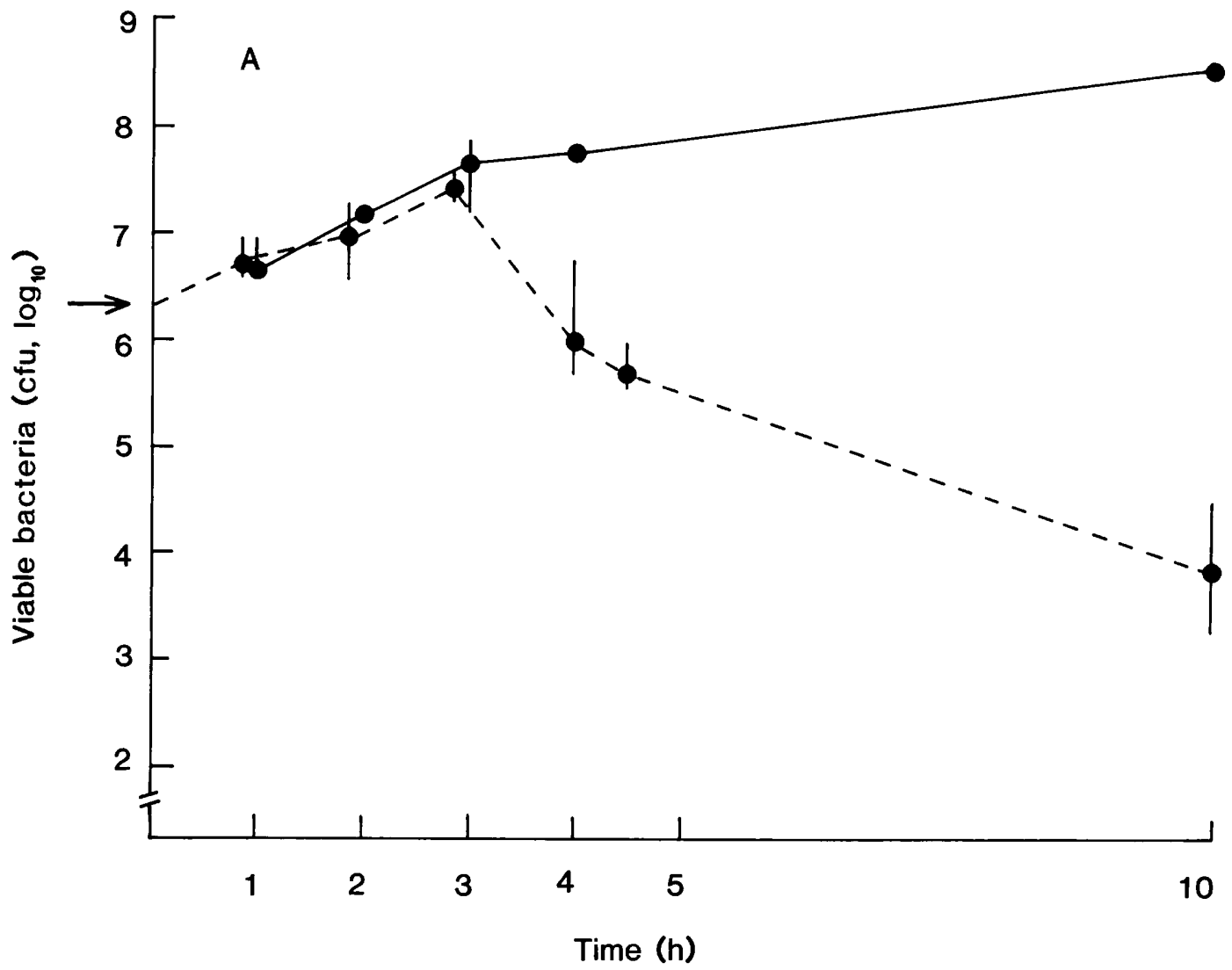

Death

by $24 \mathrm{~h}$

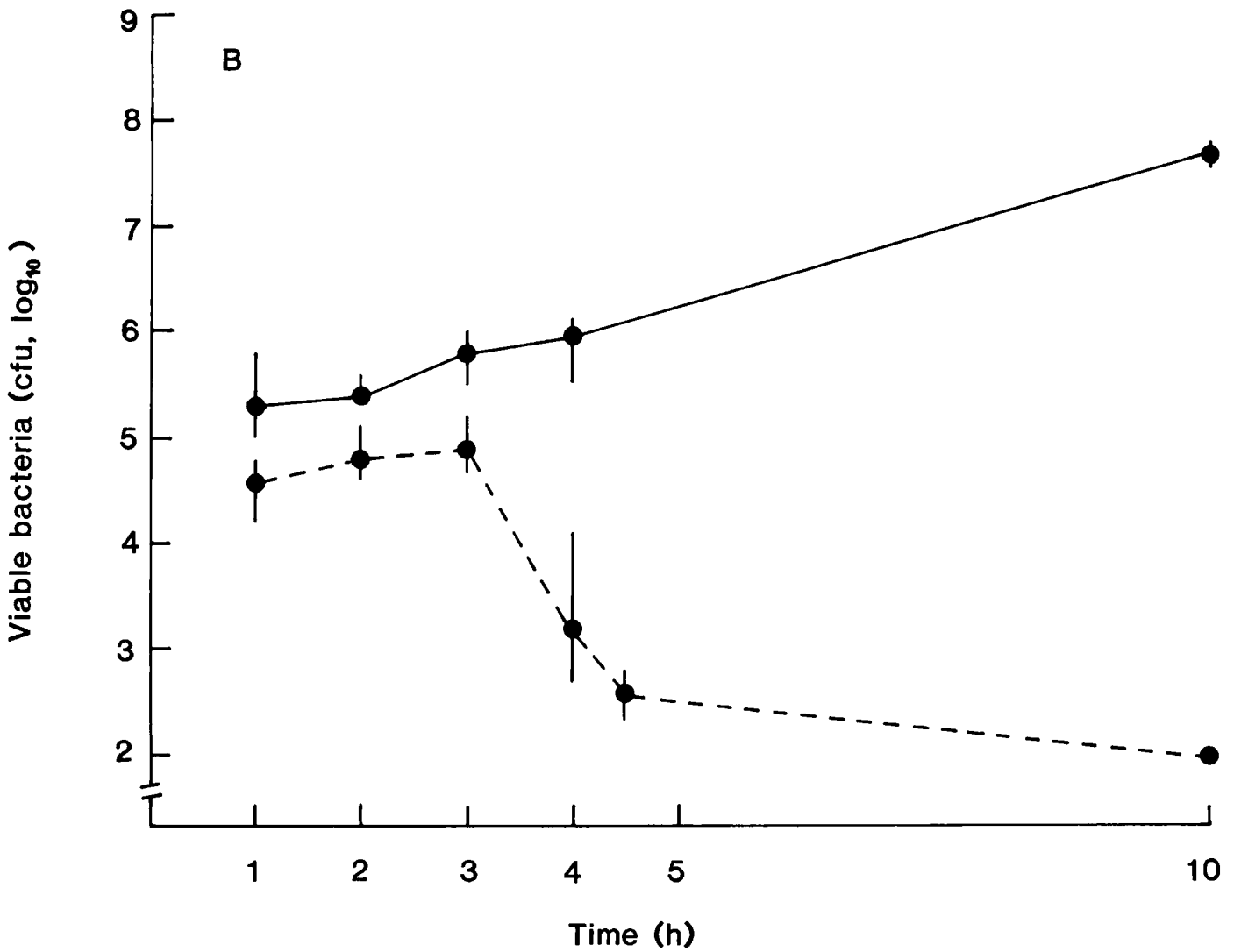

Fig. 2. Time course of $E$. coli $\mathrm{O} 18: \mathrm{K} 1$ infection in normal (-) and $\mathrm{K}-12$ LPS-treated ( $5 \mu \mathrm{g}$ of LPS sc $24 \mathrm{~h}$ before challenge) $(---)$ mice: A peritoneal cavity; B blood. The challenge dose is indicated by an arrow. Each point represents the geometric mean of results from three mice; the vertical lines show the scatter between the values. 
lenge. The mice survived, showing that LPS indeed had a protective effect. We then proceeded to characterise the LPS effect in a systematic way.

The LPS effect could be seen by $4 \mathrm{~h}$ after challenge as a reduction in the number of bacteria in the peritoneal cavity $\left(6.7 \times 10^{6} \mathrm{cfu}\right.$ compared with $7.9 \times 10^{7} \mathrm{cfu}$ in the control mice; fig. 1). The specificity of the LPS was not important; LPS purified from the rough $E$. coli $\mathrm{K}-12$ gave the same result as the homologous LPS (fig. 1).

The number of viable $E$. coli in the peritoneal cavity of the LPS-treated mice increased as in control mice for the first $3 \mathrm{~h}$ after challenge (fig. 2A). Thereafter, the number started to decrease in the LPS-treated, but not in the control, mice. The bacterial counts in the blood paralleled the bacterial growth in the peritoneal cavity (fig. 2B). By $10 \mathrm{~h}$ after challenge, the LPS-treated mice had cleared most of the injected bacteria; all these mice survived the infection that was lethal to control animals. On the basis of these experiments, $4 \mathrm{~h}$ after challenge was considered a suitable time for demonstrating the LPS effect on bacterial growth.

The route of LPS administration was not important for the development of resistance; both ip and sc injections resulted in a similar resistance in the mice (fig. 3). Subsequently, the sc route was used to avoid causing a local inflammatory reaction in the peritoneal cavity.

In the LPS-hyporesponsive mouse strain, $\mathrm{C} 3 \mathrm{H} /$ $\mathrm{HeJ}$, which was 1000 -fold more susceptible to the E. coli $\mathrm{O} 18: \mathrm{K} 1$ peritonitis, we could not show any
LPS-induced increase in resistance (data not shown).

If the interval between the injections of LPS and bacteria was $24 \mathrm{~h}$ instead of $2 \mathrm{~h}$, the LPS treatment was more effective (fig. 3). The increase in resistance lasted for 4 days from the LPS injection (data not shown) and two separate LPS injections $(5 \mu \mathrm{g} /$ injection) within $24 \mathrm{~h}$ did not further increase the efficacy of the LPS treatment as estimated by the number of viable $E$. coli in the peritoneal cavity at $4 \mathrm{~h}$ (fig. 3). Furthermore, if the mice were given four injections of LPS within 14 days $(5 \mu \mathrm{g} /$ injection, sc), the growth of a lethal $E$. coli challenge in the peritoneal cavity was prevented if the last injection was given on day 1 , but not if it was given on day 7 or day 14 before infection (data not shown).

The dose-response range for the LPS-induced resistance was rather wide (table I). Even an LPS dose of $0.5 \mu \mathrm{g} /$ mouse resulted in a 100 -fold increase in LD50. All these doses are $\leq 5 \%$ of the lethal dose which is reported to be $c .1 \mathrm{mg} /$ mouse for the K-12 LPS (Galanos et al., 1979).

\section{Effect of a detoxified LPS preparation on the E. coli O18: K1 infection}

Because of the many adverse effects of LPS, it was of interest to determine whether a less toxic LPS derivative was still effective in inducing infection resistance. When $10 \mu \mathrm{g}$ of MPL was injected sc $24 \mathrm{~h}$ before challenge with $2 \cdot 5$ LD50 of

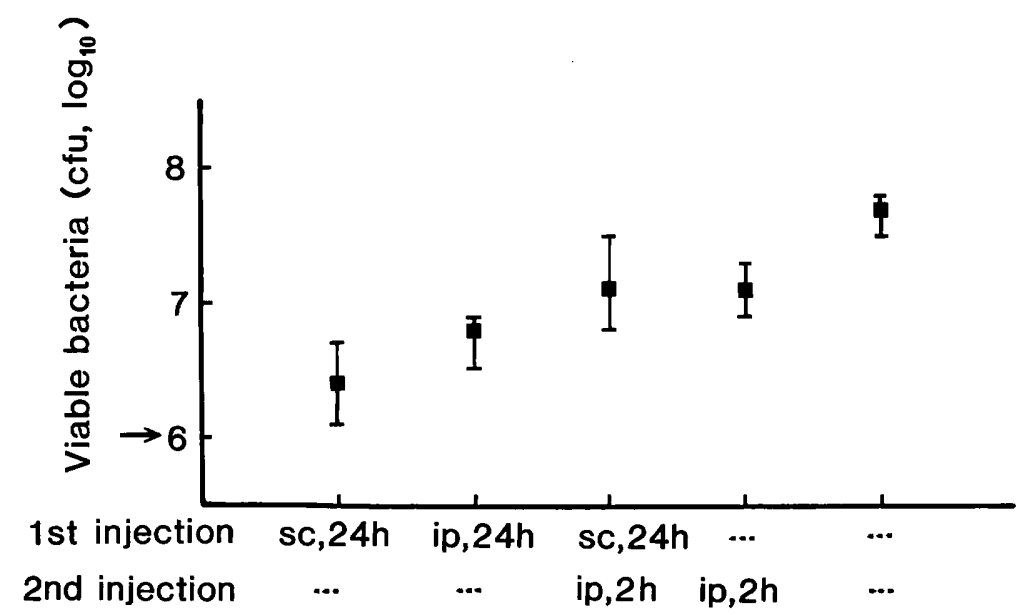

Fig. 3. The effect of timing and route of LPS administration ( $5 \mu \mathrm{g} E$. coli K-12 LPS per injection) on the numbers of viable bacteria found in the peritoneal cavities of the mice $4 \mathrm{~h}$ after challenge with $2.5 \mathrm{LD} 50$ of $E$. coli O18:K 1 . The challenge dose is indicated by an arrow. Each point represents the geometric mean of results from three mice; the vertical lines show the scatter between the values. 
Table I. Effect of LPS pretreatment $24 \mathrm{~h}$ before challenge on mortality from $E$. coli $\mathrm{O} 18: \mathrm{K} 1$ infection

\begin{tabular}{lc|cc}
\hline & & \multicolumn{2}{|c}{$\begin{array}{c}\text { Number of mice dead/total on day } \\
\text { 5 after challenge with }\end{array}$} \\
\cline { 3 - 4 } $\begin{array}{l}\text { Pretreatment } \\
\text { preparation }\end{array}$ & $\begin{array}{c}\text { Dose } \\
(\mu \mathrm{g})\end{array}$ & 100 LD50 & 10 LD50 \\
\hline K-12 LPS & 50 & $0 / 6$ & $0 / 6$ \\
injected sc & 5 & $0 / 6$ & $0 / 6$ \\
& 0.5 & $1 / 5$ & $0 / 6$ \\
& 0.05 & $\mathrm{nt}$ & $5 / 6$ \\
MPL & 0.005 & $\mathrm{nt}$ & $6 / 6$ \\
injected sc & 50 & $\mathrm{nt}$ & $0 / 6$ \\
& 5 & $\mathrm{nt}$ & $6 / 6$ \\
none & 0.5 & $\mathrm{nt}$ & $6 / 6$ \\
& & $6 / 6$ & $6 / 6$ \\
\hline
\end{tabular}

$\mathrm{nt}=$ not tested.

E. coli $\mathrm{O} 18: \mathrm{K} 1$ the mice survived and decreased numbers of viable bacteria were detected at $4 \mathrm{~h}$ in the peritoneal cavities (fig. 4). With this rather low challenge dose the effect of MPL on the early course of the infection was thus similar to that of $\mathrm{K}-12$ LPS. However, when the challenge dose was increased to $10 \mathrm{LD} 50,100$ times more $\operatorname{MPL}(50 \mu \mathrm{g})$

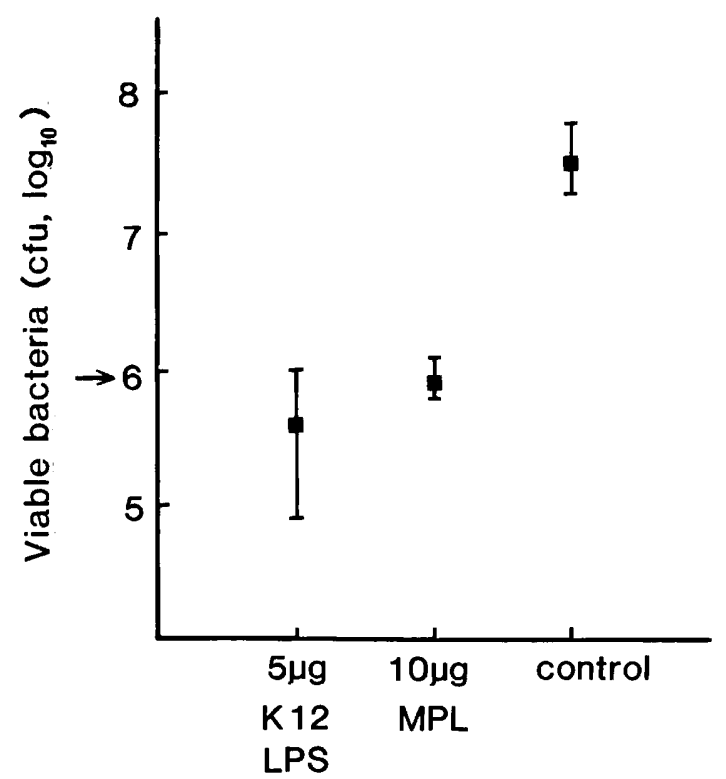

Fig. 4. The effect of different LPS preparations on the numbers of viable $E$. coli $\mathrm{O} 18: \mathrm{K} 1$ found in the peritoneal cavities of mice $4 \mathrm{~h}$ after a 2.5 LD50 challenge. The LPS preparations were injected sc $24 \mathrm{~h}$ before bacterial challenge. The challenge dose is indicated by an arrow. Each point represents the geometric mean of results with three mice; the vertical lines show the scatter between the values. than $E$. coli K-12 LPS $(0.5 \mu \mathrm{g})$ was required to allow $100 \%$ survival of the mice (table I).

To test whether the reduced ability of MPL to induce resistance to infection was associated with a similar reduction in toxicity, we compared activities of MPL and E. coli K-12 LPS in two separate toxicity assays. In galactosamine-treated mice, which are $10^{5}$-fold more sensitive than normal mice to the lethal effects of LPS (Galanos et al., 1979), an intravenous injection of MPL was 100 fold less toxic (LD50=100 ng) than $E$. coli $\mathrm{K}-12$ LPS (LD50 $=1 \mathrm{ng}$ ) (table II). In the rabbit pyrogenicity assay also, a 100-fold larger dose of MPL than $\mathrm{K}-12$ LPS was required to induce a significant fever response $(200 \mathrm{ng} / \mathrm{kg}$ and $2 \mathrm{ng} / \mathrm{kg}$ of MPL and LPS, respectively, iv) (table III).

\section{Effect of $E$. coli $K-12$ LPS pretreatment on systemic} infections with other $E$. coli strains

Because LPS pretreatment protected mice against the standard $E$. coli $\mathrm{O} 18: \mathrm{K} 1$ infection, the role of non-specific infection resistance against two other capsulate $E$. coli strains was investigated. These challenge strains were clinical isolates from neonatal septicaemia and in both cases a preinjection of rough-type $E$. coli K-12 LPS provided significant protection from a lethal bacterial challenge (table IV).

\section{Discussion}

Mice that had recovered from a sublethal $E$. coli O18:K1 infection possessed a greatly increased resistance to a subsequent challenge with a lethal dose at a time, 1-2 days after the first infection, when an antibody response would hardly have had time to develop. A similar increase in resistance

Table II. Mortality of galactosamine-sensitised mice due to LPS or MPL

\begin{tabular}{l|cc}
\hline & \multicolumn{2}{|c}{$\begin{array}{c}\text { Number of mice dead/total } 48 \mathrm{~h} \\
\text { after injection* of }\end{array}$} \\
\cline { 2 - 2 } $\begin{array}{l}\text { Galactosamine } \\
\text { dose/mouse }\end{array}$ & MPL & K-12 LPS \\
\hline $10 \mu \mathrm{g}$ & $5 / 5$ & $\mathrm{nt}$ \\
$1 \mu \mathrm{g}$ & $4 / 5$ & $\mathrm{nt}$ \\
$100 \mathrm{ng}$ & $3 / 6$ & $4 / 6$ \\
$10 \mathrm{ng}$ & $0 / 3$ & $5 / 6$ \\
$1 \mathrm{ng}$ & $\mathrm{nt}$ & $3 / 5$ \\
\hline
\end{tabular}

* LPS or MPL was injected iv in a volume of $0.2 \mathrm{ml}, 20-60 \mathrm{~min}$ after galactosamine injection. $\mathrm{nt}=$ not tested. 
Table III. Pyrogenicity of LPS and MPL preparations in rabbits

\begin{tabular}{lc|cc}
\hline Preparation & $\begin{array}{c}\text { Dose } \\
(\mathrm{ng} / \mathrm{kg})\end{array}$ & $\begin{array}{c}\text { Sum of increases } \\
\text { of temperatures } \\
\text { in 3 rabbits }\left({ }^{\circ} \mathrm{C}\right)\end{array}$ & Pyrogenicity* \\
\hline K-12 LPS & 2 & 3.20 & + \\
MPL & $0 \cdot 2$ & $1 \cdot 19$ & + \\
& 200 & 2.52 & + \\
& 20 & 0.59 & - \\
& 2 & 0.29 & - \\
\hline
\end{tabular}

* A preparation was considered to be pyrogenic if the sum was $>1 \cdot 15^{\circ} \mathrm{C}$ for 3 rabbits.

was achieved by pretreating the mice with a small dose of the homologous LPS or heterologous roughtype LPS. This suggested that LPS was the bacterial component responsible for the development of resistance.

The observation that minute LPS doses can increase the host's resistance to infection is not new (Rowley, 1955; Landy, 1956; Abernathy, 1957; Cluff, 1970; Parant, 1983). Although the exact mechanisms leading to restriction of bacterial proliferation and survival of the animals are still not known, the activation of long-living phagocytic cells (macrophages) has been considered to be important (Galelli et al., 1977). This view is also supported by studies demonstrating that LPS can induce non-specific resistance to infection in neutropenic, immunosuppressed mice, in which macrophages are believed to be the main functional phagocytic cells (Tegtmeier and Andersen, 1983; Vuopio-Varkila, 1987). From in-vitro studies it is known that LPS stimulation increases the production of interleukin 1 (IL-1) by mononuclear cells (Gery and Waksman, 1972). IL-1 release is, on the

Table IV. Effect of LPS pretreatment on mortality from different $E$. coli infections

\begin{tabular}{l|ccc}
\hline & $\begin{array}{c}\text { Number of mice dead/total on day 5 } \\
\text { after challenge with } E \text {. coli } \text { strain and } \\
\text { dose* (cfu/mouse) }\end{array}$ \\
\cline { 2 - 3 } $\begin{array}{l}018: \mathrm{K} 5 \\
\text { Pretreatment }\end{array}$ & $\begin{array}{c}01: \mathrm{K} 1 \\
\left(3.6 \times 10^{7}\right)\end{array}$ & $\begin{array}{c}018: \mathrm{K} 1 \\
\left(2 \times 10^{6}\right)\end{array}$ & $\left(4 \times 10^{6}\right)$ \\
\hline $\begin{array}{l}\text { K-12 LPS 5 } \mu \mathrm{g} / \text { mouse sc } \\
24 \mathrm{~h} \text { before challenge }\end{array}$ & $0 / 5$ & $0 / 6$ & $0 / 6$ \\
None & $6 / 6$ & $6 / 6$ & $6 / 6$ \\
\hline
\end{tabular}

* Challenge doses were $c .10 \times$ LD50. other hand, required for maximal macrophage activation.

To learn more of the mechanism of the LPSinduced infection resistance a well-characterised $E$. coli $018: \mathrm{K} 1$ infection model was used. Further evidence of the non-specific nature of the LPS effect was provided by two other $E$. coli strains against which the rough $\mathrm{K}-12$ LPS was also shown to be protective. LPS pretreatment has a similar effect on experimental infections with Klebsiella sp., group B streptococci and Listeria monocytogenes infections in the mice (Vuopio-Varkila, unpublished observations). The finding that the LPS can be injected in a site different from that of the bacterial challenge site suggests that a systemic, non-specific cell activation was responsible for the effect. In the $\mathrm{C} 3 \mathrm{H} / \mathrm{HeJ}$ (LPS-hyporesponsive) mice, LPS pretreatment failed to increase resistance to $E$. coli $\mathrm{O} 18: \mathrm{K} 1$ peritonitis. Similar results have been reported in an experimental klebsiella infection model (Chedid et al., 1976). This mouse strain is known to be defective in many B-cell and macrophage responses to LPS as well as in induction of acute-phase serum proteins after LPS administration (Rosenstreich, 1985). Also, IL-1 release from macrophages is deficient in these mice (Rosenstreich, 1985). Thus, this finding gives further evidence for the important role of macrophages in LPS-induced infection resistance.

In normal mice, $E$. coli $\mathrm{O} 18: \mathrm{K} 1 \mathrm{multiplies} \mathrm{rapidly}$ in the peritoneal cavity and, with a high challenge dose, this leads to death in 24-48 h. In LPS-treated mice, the challenge organisms multiplied in a similar manner for the first 3-4 h but thereafter the numbers of viable bacteria started to decline and the mice survived. The decrease in bacterial numbers, and resulting recovery, were similar to events in control mice challenged with a smaller inoculum, but occurred much earlier.

The known adverse effects of LPS, such as fever, hypotension, the local Shwartzman reaction, are ascribed to the lipid A part of endotoxin (Luderitz et al., 1978). Recently, attention has been directed to the possible use of LPS derivatives with less toxic effects such as the chemically-modified, monophosphoryl lipid A (MPL; Ribi, 1984). It has also become evident that detoxification of bacterial LPSs may take place in vivo by the enzymic activity of human neutrophils (Munford and Hall, 1986).

Our studies with MPL revealed that although it was 100 -fold less toxic for rabbits and mice, as measured by fever induction or lethal toxicity, 100fold larger doses were required for optimal resistance to infection compared to native rough-type LPS. No such relationship has been previously 
reported for MPL but in most other studies its effects have not been quantitated (Chase et al., 1986; Madonna et al., 1986; Masihi et al., 1986). In fact, the pyrogenic and mitogenic actions of IL-1 appeared to be related (Duff and Durum, 1983), suggesting that if fever induction were reduced then the macrophage activation step also would be

\section{REFERENCES}

Abernathy R S 1957 Homologous and heterologous resistance in mice given bacterial endotoxins. Journal of Immunology 78:387-394.

Antoni $\mathrm{G}$ et al. 1986 A short synthetic peptide fragment of human interleukin 1 with immunostimulatory but not inflammatory activity. Journal of Immunology 137:32013204.

Chase J J et al. 1986 Effect of monophosphoryl lipid A on host resistance to bacterial infection. Infection and Immunity 53:711-712.

Chedid L, Parant M, Damais C, Parant F, Juy D, Galelli A 1976 Failure of endotoxin to increase nonspecific resistance to infection of lipopolysaccharide low-responder mice. Infection and Immunity 13:722-727.

Cluff L E 1970 Effects of endotoxins on susceptibility to infections. Journal of Infectious Diseases 122:205-215.

Duff G W, Durum S K 1983 The pyrogenic and mitogenic actions of interleukin-1 are related. Nature 304:449-451.

European pharmacopoeia 1971 Vol. II, Maisonneuve, France pp. 53-61.

Galanos C, Lüderitz O, Westphal O 1969 A new method for the extraction of $\mathrm{R}$ lipopolysaccharides. European Journal of Biochemistry 9:245-249.

Galanos C, Freudenberg M A, Reutter W 1979 Galactosamineinduced sensitization to the lethal effects of endotoxin. Proceedings of the National Academy of Sciences of the USA 76: $5939-5943$.

Galelli A, Parant M, Chedid L 1977 Role of radiosensitive and radioresistant cells in nonspecific resistance to infection of LPS-treated mice. Journal of the Reticuloendothelial Society 21: $109-118$.

Gery I, Waksman B H 1972 Potentiation of the T-lymphocyte response to mitogens. II. The cellular source of potentiating mediator(s). Journal of Experimental Medicine 136: 143-155.

Landy M 1956 Increase in resistance following administration of bacterial lipopolysaccharides. Annals of the New York Academy of Sciences 66:292-303.

Luderitz O, Galanos C, Lehmann V, Mayer H, Rietschel E T, Weckesser J 1978 Chemical structure and biological activities of lipid A's from various bacterial families. Naturwissenschaften 65 : 578-585.

Madonna G S, Peterson J E, Ribi E, Vogel S N 1986 Earlyphase endotoxin tolerance: induction by a detoxified lipid A derivative, monophosphoryl lipid A. Infection and Immunity 52:6-11.

Masihi K N, Lange W, Johnson A G, Ribi E 1986 Enhancement limited. However, a recent report has described a short peptide fragment of human IL-1 devoid of pyrogenic activity but still potent in immunostimulation (Antoni et al., 1986).

This study was supported by SITRA, the Finnish National Fund for Research and Development.

of chemiluminescence and phagocytic activities by nontoxic and toxic forms of lipid A. Journal of Biological Response Modifiers 5: 462-469.

Miller J H 1972 Experiments in molecular genetics. Cold Spring Harbor Laboratory, New York.

Munford R S, Hall C L 1986 Detoxification of bacterial lipopolysaccharides (endotoxins) by a human neutrophil enzyme. Science 234: 203-205.

Nowotny A 1985 Antitumor effects of endotoxin. In: Berry L J (ed) Handbook of endotoxins, vol. 3: Cellular biology of endotoxin, Elsevier, Amsterdam pp. 389-448.

Parant M 1983 Effect of LPS on nonspecific resistance to bacterial infections. In Nowotny A (ed) Beneficial Effects of Endotoxins, Plenum Press, New York pp. 179-196.

Reed L J, Muench H 1938 A simple method of estimating fifty per cent end-points. American Journal of Hygiene 27:493497.

Ribi E 1984 Beneficial modification of the endotoxin molecule. Journal of Biological Response Modifiers 3: 1-9.

Ribi E, Cantrell J, Feldner T, Myers K, Peterson J 1986 Biological activities of monophosphoryl lipid A. In: Leive L (ed) Microbiology 1986 American Society for Microbiology, Washington D.C., pp. 9-13.

Rosenstreich D L 1985 Genetic control of endotoxin response: $\mathrm{C} 3 \mathrm{H} / \mathrm{HeJ}$ mice. In : Berry L J (ed) Handbook of endotoxins, vol. 3: Cellular biology of endotoxin. Elsevier, Amsterdam, pp. 82-122.

Rowley D 1955 Stimulation of natural immunity to Escherichia coli infections. Observations on mice. Lancet 1:232-234.

Tegtmeier B R, Andersen B R 1983 Mechanisms of lipopolysaccharide-induced protection against Pseudomonas sepsis in granulocytopenic mice. Reviews of Infectious Diseases 5 (Suppl): S963-S969.

Vaara M, Viljanen P, Vaara T, Mäkelä P H 1984 An outer membrane-disorganizing peptide $\mathrm{PMBN}$ sensitizes $E$. coli strains to serum bactericidal action. Journal of Immunology 132: $2582-2589$.

Vuopio-Varkila J 1988 Experimental Escherichia coli peritonitis in immunosuppressed mice; the role of specific and nonspecific resistance mechanisms. Journal of Medical Microbiology 25:33-39.

Vuopio-Varkila J, Karvonen M, Saxén H 1988 The protective capacity of antibodies to various outer membrane components in a systemic mouse peritonitis model caused by Escherichia coli O18:K1. Journal of Medical Microbiology. In press.

Westphal O, Jann K 1965 Bacterial lipopolysaccharides. Extraction with phenol-water and further applications of the procedure. Methods in Carbohydrate Chemistry 5:83-91. 